\title{
Association between CYP2C19*2 variant and clinical outcome in Clopidogrel treated patients from Republic of Macedonia
}

\author{
Aleksandra Kapedanovska Nestorovska ${ }^{1}$, Aleksandra Dimitrovska Cvetkovska ${ }^{2}$, \\ Ljubica Suturkova*1
}

${ }^{1}$ Faculty of Pharmacy, University of Ss Cyril and Methodius, Skopje, R.Macedonia, ${ }^{2}$ Special Hospital for Surgery Diseases "Filip II", Skopje, R.Macedonia

Received: April 2011; Accepted: June 2011

\begin{abstract}
Clopidogrel is the thienopyridine of choice for prevention of ischemic events and stent thrombosis in patients with atherotrombotic disease. Recent studies suggest that certain genetic variants involving CYP450 system are responsible for wide interindividual variability in treatment response profiles among clopidogrel treated individuals. The aim of this study was to define the prevalence of most common CYP2C19*2: 681G>A (rs4244285) allelic variant in Macedonian population and determine the risk association with major cardiovascular adverse events in clopidogrel treated patients with atherotrombotic cardiovascular disease.

CYP2C19 *2 genotype was assessed in 198 subjects from R.Macedonia. The association between the reduced function CYP2C19 *2 A allele and clinical outcome was evaluated in 67 clopidogrel treated patients within a follow up period of at least 6 months (from 6 to 60 months) after initializing clopidogrel therapy.

The population frequency of polymorphic A allele responsible for impaired clopidogrel metabolism in Macedonian population was 0.18 . CYP2C19*2 variant was significantly associated with increased rate of adverse cardiovascular events in the allelic $(\mathrm{OR}=3.188 ; 95 \%$ $\mathrm{CI}=1.437-7.058)$, dominant $(\mathrm{OR}=3.477 ; 95 \% \mathrm{CI}=1.256-9.630)$ and co-dominant model ( $\mathrm{OR}=6.750,95 \% \mathrm{CI}: 1.186-38.410)$ of statistical analysis (adjusted $\mathrm{OR}=2.619 ; \mathrm{P}_{\text {trend }}=0.0088$ ). The influence of $\mathrm{CYP} 2 \mathrm{C} 19 * 2$ was most strongly correlated with worse event free survival in patients carrying AA genotype $(\log$ rank $\mathrm{P}=0.0024)$ and patients carrying at least one $\mathrm{CYP} 2 \mathrm{C} 19 * 2$ reduced function allele $(\log$ rank $\mathrm{P}=0.0058$ ).

CYP2C19*2 genetic variant in the population from Republic of Macedonia has similar distribution as determined in other European populations. Carriage of reduced function CYP2C19*2 allele is associated with worse event free survival in clopidogrel treated patients with atherotrombotic disorders.
\end{abstract}

Key words: clopidogrel, Macedonia, CYP2C19*2, atherotrombotic disease, adverse cardiovascular events, event free survival

\section{Introduction}

Atherosclerotic vascular disease has a predisposition to provoke arterial thrombosis, a sequence that has been called atherotrombotic process. Collectively, atherotrombotic disorders (ATD) of the coronary, cerebrovascular and peripheral arterial circulation are the leading cause of death and disability in the world (Bhatt et al., 2006). Clopidogrel, because of the more favorable safety profile (Bertrand et

* ljsu@ff.ukim.edu.mk al. 2000), is the thienopyridine of choice in prevention of ischemic events and stent thrombosis in patients with ATD and patients undergoing percutaneus coronary intervention (PCI) with or without stenting (Grubel et al., 2003; Steinhbul et al., 2001). It's active thiol metabolite selectively and irreversibly inhibits ADP mediated platelet aggregation by blocking platelet P2Y12 adenosine diphosphate receptors (Grubel and Tantry, 2007). It is mainly used as an adjunctive antithrombotic therapy with aspirin (Yusuf et al., 2001; Sabatine et al., 2005).

Clopidogrel is a prodrug which, after P -glycoprotein mediated absorption, $85 \%$ is metabolized into an inac- 
tive compound and only $15 \%$ undergoes cytochrome P450 (CYP) metabolic oxidation to 2 - oxo clopidogrel which is subsequently hydrolyzed to its highly unstable active thiol metabolite. Accumulating data have shown that there is wide interindividual variability in treatmen response among clopidogrel treated patients (Angiolillo et al., 2007). Several clinical, genetic and cellular factors have been involved in this interindividual response heterogeneity (Geisler et al., 2008).

The most clinically important genetic variants, influencing clopidogrel antiplatelet's effects, are those involving human CYP2C subfamily (Goldstein et al., 2001). Of these, CYP2C19 was shown to be most consistent with the literature data (Mega et al., 2009; Simon et al., 2009), possibly because it contributes in both of the two sequential oxidative metabolic steps of clopidogrel activation (Hulot et al., 2006).

The CYP2C19 contains several Single Nucleotide Polymorphisms (SNP), some of which reduce or abolish the enzymatic activity of CYP2C19 protein and therefore are referred as reduced fnction alleles. In patients who are carriers of a reduced function CYP2C19 allele, the conversion of clopidogrel to its active metabolite may be diminished, resulting in lower amount of active metabolite, decreased inhibition of platelets and higher adverse event rates. According to this, patients are classified into categories of metabolizer phenotypes as "extensive metabolizers" - those with no reduced function allele, "intermediate metabolizers" - those with one reduced function allele and "poor metabolizers"- those with two reduced function alleles, with the use of established common consensus star allele nomenclature (Ingelman-Sundelberg et al., 2007).

Currently the majority of data assessing clopidogrel therapy focuses on the most common allelic variants of CYP2C19 (*2 and *3), which accounts for $95 \%$ of poor metabolizer (PM) phenotypes (Simon et al., 2009). Other more rare alleles causing deficient metabolism are CYP2C19*4, *5, *6, *7, *8, and CYP2C19*17 which on the other hand, results in increased enzyme activity (Dahl and Gunes, 2010).

A number of large scale studies confirmed the prognostic implications of the CYP2C19*2 variant in clopidogrel treated patients. The defining SNP of the CYP2C19*2 haplotype, CYP2C19:681G>A (rs4244285) variant has been associated with increased adverse cardiovascular event (ACE) (stent thrombosis, death, myocardial infarction and stroke) rates, poorer cardiovascular outcomes and attenuated therapy benefits in clopidogrel treated patients (Marin et al., 2009; Shuldiner et al., 2009; Collet et al., 2009; Gladding et al., 2008; Simon et al., 2009, Harmsze et al., 2010). Marked population diversities regarding frequencies of rs4244285 minor A allele has been documented. The prevalence of reduced function (A) allele is approximately 0.15 in Caucasians, 0.17 in African Americans, 0.25 in Chinese and 0.28 in Japanese (Fontana et al., 2007).

The importance of these strong genetic effects was recognized by The Food and Drug Administration which add- ed its strongest warnings to the clopidogrel label, cautioning that certain patients carrying two reduce function alleles cannot metabolize the drug, putting them at increased risk for heart attack and stroke and suggested that those patients need higher dose of clopidogrel or an alternative antiplatelet agent.

The aim of this study was to define the prevalence of most common CYP2C19*2 (rs4244285) allelic variant in population in Macedonian and determine the association between reduced function allele and risk of major ACE in clopidogrel treated patients with atherotrombotic cardiovascular disease (ACD)

\section{Materials and methods}

\section{Patients}

From October 2010 to December 2010, patients presenting at Special Hospital for Surgery Diseases "Filip II", were consequently enrolled in this pharmacogenetic study. All the included subjects were of Caucasian origin. Total number of 198 patient (127 male and 71 female, mean age $60,57 \pm 8,49$ years), were genotyped for CYP2C19*2 polymorphism.

Analysis of clinical outcome in carriers and noncarriers of reduced function CYP2C19*2 A allele was limited to 67 clopidogrel treated patients. Major inclusion criteria was the use of clopidogrel therapy because of established cardiovascular disease (PCI- with or without stent, acute coronary syndrome- ACS, myocardial infarction-MI; coronary artery disease - CAD; coronary artery bypass graft-CABG, peripheral arterial disease-PAD; cerebrovascular disease-CVA), or multiple atherotrombotic risk factors (Type 1 or 2 diabetes, primary hypercholesterolemia, asymptomatic carotid stenosis). The loading dose of clopidogrel during hospitalization was $600 \mathrm{mg}$ per day and the maintenance dose at the time of hospital discharge and therapy period after hospitalization was $75 \mathrm{mg}$ per day.

Patients were excluded if they had 1) prior history of bleeding (e.g. peptic ulcer, intracranial hemorrhage, menstrual bleeding), 2) clinically significant abnormality or abnormal laboratory assessment regarding platelet function before and during follow up study period, 3) concomitant use of other drugs known to modify hepatic drug metabolism, 4) drug addiction or excessive use of alcohol and 5) blood donation within the last 2 months before initialization of clopidogrel therapy. Female patients were not included in the study if they were on hormone replacement therapy or had intra-uterine contraception device.

Clinical outcome was evaluated within a follow up period of at least 6 months (from 6 to 60 months) after initializing clopidogrel therapy. The primary efficacy end point was the first clinical occurrence of any of the following ACE: death, periprocedural myocardial infarction, stent thrombosis, stroke, hospitalization because of unstable angina, transient ischemic attack and re-intervention (revas- 
cularization) during exposure to or after clopidogrel therapy. Follow-up time for Event-Free Survival (EFS) analysis was measured from the date of initializing clopidogrel therapy to the earlier of the first event or last contact alive. Follow-up informations were collected through contacts with the patients' physicians, the patients or their family. All subjects were included in the study after giving informed consent. The study was approved by the Ethics committee of the Faculty of Pharmacy- Skopje.

\section{Genotyping procedures}

Genomic DNA was isolated from peripheral blood using Proteinase $\mathrm{K}$ digestion/phenol-chloroform extraction and ethanol precipitation. Purity was verified by UV absorption at 260/280 nm and DNA integrity was confirmed by electrophoresis in $0,8 \%$ agarose gels, stained with ethidium bromide. The CYP2C19*2 polymorphism [rs4244285] was genotyped by Real-Time PCR [MxPro 3005P, Stratagene, La Jolla, CA, USA] using TaqMan SNP genotyping assay according to the manufacturer instructions [Applied Biosystems, Foster City, CA, USA].

\section{Statistical Analysis}

SISA statistical software package was used to perform Chi-squared analysis and Fishers Exact Test. Odds ratios [OR] were calculated with $95 \%$ confidence limits $[95 \%$ $\mathrm{CI}$. Allele frequencies and allelic distribution were analyzed for Hardy-Weinberg equilibrium.

To examine separate and combined effects of the CYP2C19*2 genotype, certain risk factors (age and gender of the patients, NYHA and APS-CCS status, laboratory data, diabetes mellitus, prior MI, PCI with or without stenting), as well as rate of ACE, stratified analyses were conducted.

Clinical outcome rates (EFS analysis) were made by the Kaplan-Meier method. Differences in survival parameters were assessed for significance by means of the log- rank test. Factors with $\mathrm{p} \leq 0.05$ were considered statistically significant.

\section{Results}

Genotype distributions and allelic frequencies of CYP2C19 *2 genetic variant regarding the two study groups (population group and clopidogrel treated patients) are presented in Table 1 . The population frequency of polymorphic CYP2C19*2 A allele responsible for impaired drug metabolism was 0.18 . The prevalence of subjects homozygous for the wild type allele (GG genotype) was 0.67 , compared to patients heterozygous for the reduced function allele (AG genotype) and homozygous for the reduced function allele (AA genotype), 0.28 and 0.045 , respectively. The observed genotype distributions did not significantly deviate from Hardy-Weinberg equilibrium.

The effect of the CYP2C19*2 variant on clopidogrel treatment outcome was assessed in total of 67 patients. All clopidogrel treated patients, according to the occurrence of ACE with a median of 12 months (range 6 to 60 months) of follow up after initializing the clopidogrel therapy, were randomized in to two patient subgroups. The responders (control) group consisted of 38 (57\%) patients who did not developed any ACE and the non - responders group consisted of 29 (43\%) patients who developed ACE during the follow up period. Demographic and disease characteristics of patients included in the clopidogrel therapy outcome evaluation are summarized in Table 2.

Genotype and allelic frequencies of the control (responders) group were similar to those previously reported for the healthy Caucasian populations. No significant deviations from Hardy-Weinberg equilibrium were observed. The CYP2C19*2 [G/A] genotype frequencies within responders and nonresponder groups were significantly different, owing predominantly to a significant excess of reduced function ' $A$ ' allele homozygotes in the no responders group (Table 3).

Table 1. Genotype distribution and allelic frequencies of CYP2C19 $* 2$ genetic variant in study groups

\begin{tabular}{rcccccc}
\hline \hline & \multicolumn{3}{c}{$\begin{array}{c}\text { Population from R.Macedonia } \\
(\mathrm{N}=198)\end{array}$} & \multicolumn{3}{c}{$\begin{array}{c}\text { Clopidogrel treated patients } \\
(\mathrm{N}=67)\end{array}$} \\
\hline $\begin{array}{r}\text { CYP2C19*2 } \\
\text { polymorphism } \\
{[\text { rs4244285] }}\end{array}$ & $\mathrm{n}$ & $\begin{array}{c}\text { frequencies } \\
(*)\end{array}$ & $\begin{array}{c}\text { expected } \\
\text { frequencies } \\
(*)\end{array}$ & $\mathrm{n}$ & $\begin{array}{c}\text { frequencies } \\
(*)\end{array}$ & $\begin{array}{c}\text { expected } \\
\text { frequencies } \\
(*)\end{array}$ \\
GG & 133 & 67.17 & 66.24 & 39 & 58.2 & 53.29 \\
GA & 56 & 28.28 & 30.39 & 20 & 29.9 & 39.3 \\
AA & 9 & 4.55 & 3.49 & 8 & 11.9 & 7.23 \\
G allele & 322 & 81.31 & & & & \\
A allele & 74 & 18.69 & & 36 & 26.9 & \\
\hline
\end{tabular}


Table 2. Demographic and disease details of the patients monitored for response to clopidogrel therapy

\begin{tabular}{|c|c|c|c|c|c|c|}
\hline Caracteristics & \multicolumn{2}{|c|}{$\begin{array}{c}\text { All patients }(\mathrm{N}=67) \\
\mathrm{n}(\%)\end{array}$} & \multicolumn{2}{|c|}{$\begin{array}{l}\text { Responders }(\mathrm{N}=38) \\
\mathrm{n}(\%)\end{array}$} & \multicolumn{2}{|c|}{$\begin{array}{c}\text { Non responders }(\mathrm{N}=29) \\
\mathrm{n}(\%)\end{array}$} \\
\hline \multicolumn{7}{|l|}{ Gender } \\
\hline Male & 45 & $(67,16)$ & 21 & $(55,26)$ & 24 & $(82,75)$ \\
\hline Female & 22 & $(32,83)$ & 17 & $(44,74)$ & 5 & $(17,25)$ \\
\hline \multicolumn{7}{|l|}{ Age } \\
\hline$>50$ & 13 & $(19,40)$ & 6 & $(15,78)$ & 7 & $(24,13)$ \\
\hline$</=50$ & 54 & $(81,59)$ & 32 & $(84,21)$ & 22 & $(75,87)$ \\
\hline \multicolumn{7}{|l|}{ Diabetes melitus } \\
\hline Yes & 33 & $(49,25)$ & 13 & $(34,21)$ & 20 & $(68,96)$ \\
\hline No & 34 & $(51,75)$ & 25 & $(65,78)$ & 9 & $(31,03)$ \\
\hline \multicolumn{7}{|l|}{ Indication for clopidogrel therapy } \\
\hline $\begin{array}{r}\text { PCI } \\
\text { ( with or without stent) }\end{array}$ & 18 & $(26,86)$ & 13 & $(34,21)$ & 5 & $(17,24)$ \\
\hline MI & 11 & $(16,41)$ & 5 & $(13,15)$ & 6 & $(20,68)$ \\
\hline ACS & 4 & $(5,97)$ & 3 & $(7,89)$ & 1 & $(3,44)$ \\
\hline CAD & 21 & $(31,34)$ & 14 & $(36,84)$ & 7 & $(24,13)$ \\
\hline CABG & 3 & $(4,47)$ & 2 & $(5,26)$ & 1 & $(3,44)$ \\
\hline CVA & 1 & $(1,49)$ & 0 & 0 & 1 & $(3,44)$ \\
\hline PVD & 3 & $(4,47)$ & 0 & 0 & 3 & $(10,34)$ \\
\hline multiple atherotrombotic risk factors & 6 & $(8,95)$ & 1 & $(2,63)$ & 5 & $(17,24)$ \\
\hline
\end{tabular}

Table 3. Risk of adverse cardiovascular events associated with CYP2C19*2 polymorphism [rs4244285] in clopidogrel treated patients from R.Macedonia

\begin{tabular}{|c|c|c|c|c|c|c|c|c|c|}
\hline $\begin{array}{l}\text { Model of } \\
\text { statistical }\end{array}$ & \multicolumn{4}{|c|}{ Responders } & \multicolumn{2}{|c|}{ Non responders } & \multirow[t]{2}{*}{ OR } & \multirow[t]{2}{*}{$95 \% \mathrm{CI}$} & \multirow[t]{2}{*}{$\mathrm{p}$ value } \\
\hline Co- dominant & $\mathrm{n}$ & $\begin{array}{c}\text { Frequencies } \\
(\%)\end{array}$ & $\begin{array}{c}\text { Expected } \\
\text { frequencies (\%) }\end{array}$ & $\mathrm{n}$ & $\begin{array}{l}\text { Frequencies } \\
(\%)\end{array}$ & $\begin{array}{c}\text { Expected } \\
\text { frequencies }(\%)\end{array}$ & & & \\
\hline GG & 27 & 71.05 & 68.70 & 12 & 41.38 & 36.49 & 1.00 & & \\
\hline GA & 9 & 23.68 & 28.36 & 11 & 37.93 & 47.84 & 2.750 & $0.904-8.368$ & 0.07085 \\
\hline $\mathrm{AA}$ & 2 & 5.26 & 2.92 & 6 & 20.69 & 15.72 & 6.750 & $1.186-38.410$ & 0.01906 \\
\hline \multicolumn{10}{|l|}{ Dominant } \\
\hline GG & 27 & 71.05 & & 12 & 41.38 & & 1.00 & & \\
\hline $\mathrm{AA}+\mathrm{GA}$ & 11 & 28.95 & & 17 & 58.62 & & 3.477 & $1.256-9.630$ & 0.01469 \\
\hline \multicolumn{10}{|l|}{ Allelic } \\
\hline G allele & 63 & 82.89 & & 35 & 60.34 & & 1.00 & & \\
\hline A allele & 13 & 17.11 & & 23 & 39.65 & & 3.185 & $1.437-7.058$ & 0.00353 \\
\hline
\end{tabular}

CYP2C19*2 [G/A] variant was associated with increased risk of overall cardiovascular events in the allelic ( $\mathrm{G}$ allele $v s$. A allele), dominant (GG vs. GA+AA) and co-dominant model (GG vs. GA and GG vs. AA) of statistical analysis (adjusted $\mathrm{OR}=2.619 ; \mathrm{P}_{\text {trend }}=0.0088$ ). Allele frequency analysis revealed that the CYP2C19*2 ' $\mathrm{A}$ ' allele carriers had approximately three times higher risk for subsequent adverse cardiovascular events compared to noncarriers $(39.65 \%$ vs. $17.11 \%$; OR $=3.188 ; 95 \% \mathrm{CI}=$ [1.437-7.058], $\mathrm{p}=0.00353)$. This association remained significant also in the dominant model of statistical analysis; $(58.62 \%$ vs. $28.95 \%$; OR $=3.477,95 \% \mathrm{CI}=1.256-9.630$, $\mathrm{p}=0.0147)$. In the co-dominant model of statistical analysis, patients carrying two CYP2C19*2 reduced function al- 
leles, were at even higher risk for adverse cardiovascular events compared to patients homozygotes for CYP2C19*2 wild type allele $(20.69 \%$ vs. $5.26 \%$; OR=6.750, $95 \% \mathrm{CI}$ : $1.186-38.410, \mathrm{p}=0.01906)$. There was no significant association between CYP2C19*2 variant and overall risk of CE regarding the age, gender, different indications for clopidogrel therapy and diabetes mellitus. No significant correlation between CYP2C19*2 variant and specific efficacy end point (ACE) was observed.

A.

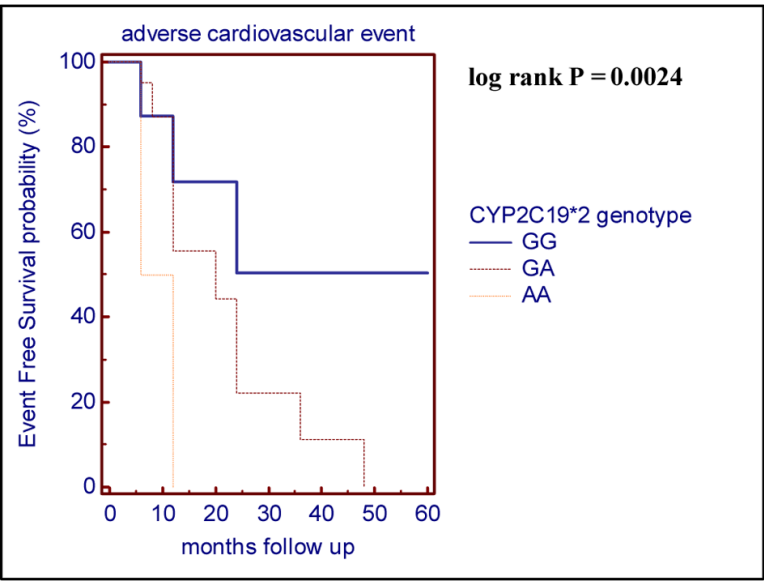

$B$.

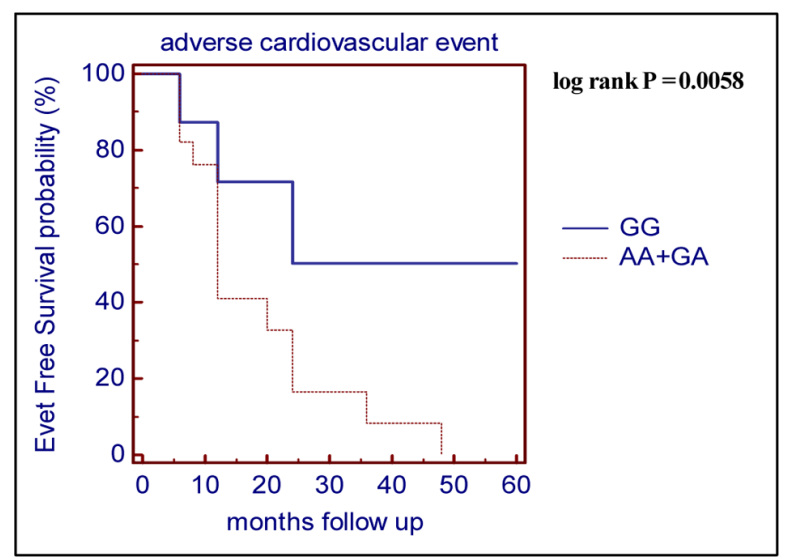

Fig.2. Kaplan Meier Curves show worse EFS for patients: (A) with AA genotype compared to GG and GA genotype patients and (B) carrying at least one CYP2C19*2 reduced function allele (AA+GA genotype vs. GG genotype).

Kaplan-Meier analysis (Fig. 2) confirmed the impact of the CYP2C19*2 genotype on EFS by evidencing a significantly worse therapeutic outcome in patients carrying AA genotype (GG vs. GA vs. AA genotype; log rank $\mathrm{P}=$ $0.0024)$ (Fig. 2A). The adverse impact of CYP2C19*2 reduced function allele on EFS was dramatically increased when carriers of at least one A allele were compared to noncariers (GG vs. GA+AA genotype; $\log$ rank $\mathrm{P}=0.0058$ ) (Fig. 2B). We also tested for interaction between reduced function carrier status and other risk factors (age, gender, prior MI, PCI with or without stenting, CAD, diabetes mel- litus, NYHA) and the time to the first adverse event after initiation of clopidogrel treatment. No significant associations were observed.

\section{Discussion}

This population based case - control study aimed to define the prevalence of the CYP2C19*2 variant in the population in the Republic of Macedonian and determine its influence on the therapeutic outcome in clopidogrel treated patients. The frequency of the most common CYP2C19*2 allelic variant in our population (18\%) was comparable to that found in other European populations: $13.3 \%$ Dutch, 15\% German, 13\% French, 15\% Swedish and 15\% Croatians (Goldstein et al., 1997; Yamada et al., 1998, Bozina et al., 2003). The genotype distributions also corresponded to those for other European white populations. This is the first study which estimates the distribution of the CYP2C19*2 in R.M.

Variability of the interindividual antiplatelet therapy is especially problematic because the therapeutic dose is mostly empirically defined, which can lead to over-antiplatelet effect (overdosing) with potential bleeding complications or underantiplatelet effect (subdosing) with potential thrombotic events. Apart from the small number of clopidogrel treated patients, we confirmed that CYP2C19*2 loss of function allele was significantly associated with 3.18 fold increased risk of developing ACE in our population. The risk for adverse cardiovascular events was even 6.7 fold increased in AA genotype patients - "poor metabolizers", compared to patients carrying GG genotype - "extensive metabolizers". The CYP2C19*2 variant is associated with worse clopidogrel therapy outcome. More important, our results regarding CYP2C19*2 genotype - related therapy outcome showed worse Event Free Survival in "intermediate" and "poor metapolizer" phenotype patients as compared to those classified as "extensive metabolizers" and are in accordance with the results from recently published studies (Pare et al., 2010) for patients followed up to one year. All of the observed ACE were associated with subdosing and occurred while on maintance therapy with $75 \mathrm{mg}$ clopidogrel per day. Absence of the ACE during hospitalization can be explained by the fact that some of the patients during this period of time were on concomitant anticoagulant therapy with unfractioned heparin or low molecular weight heparin. These observations are implying that patient specific response and resistance to clopidogrel does not occur over time and sets the stage for additional studies to determine whether genotype based clopidogrel dose adjustment would increase the plasma levels of active metabolite and overcome interindividual differences in drug response (Grubel et al., 2003).

However, there are some limitations in this study. In this stage of the study we cannot evaluate weather lowering the clopidogrel dose to $75 \mathrm{mg}$ per day after hospitalization period or low compliance to clopidogrel therapy is the 
cause for the subdosing associated adverse effects. Also, we studied only one of the CYP2C19 most common functional alleles. The low allele frequency of other CYP2C19 variants may not alter our conclusion but can be relevant for individual patients.

\section{Conclusion}

The CYP2C19*2 genetic variant in population from Republic of Macedonia has similar distribution as those reported in other European populations. Patients carrying at least one reduced function CYP2C19*2 allele are at increased risk of adverse cardiovascular events associated with suboptimal clopidogrel dosing regimens. Additionally, we have shown that CYP2C19*2 variant is associated with worse event free survival in clopidogrel treated patients. Our study illustrates variable treatment response to the standard maintance dose of clopidogrel and supports further investigations for patient specific individualisation of the clopidogrel treatment protocols in order to improve the clopidogrel therapeutic outcome.

\section{References:}

Angiolillo, DJ., Fernandez-Ortiz, A., Bernardo, E., Alfonso, F., Macaya, C., Bass, TA., Costa, MA., 2007. Variability in individual responsiveness to clopidogrel. Clinical implications, management, and future perspectives. J. Am. Coll. Cardiol. 49, 1505-1516.

Bertrand, ME., Rupprecht, HJ., Urban, P., Gershlick, A.H.; CLASSICS Investigators. Double-blind study of the safety of clopidogrel with and without a loading dose in combination with aspirin compared with ticlopidine in combination with aspirin after coronary stenting: the clopidogrel aspirin stent international cooperative study (CLASSICS)., 2000. Circulation 102(6), 624-629.

Bhatt, D.L., Fox, K.A., Hacke, W., Berger, P.B., Black, H.R., Boden, W.E., Cacoub, P., Cohen, E.A., Creager, M.A., Easton, J.D., Flather, M.D., Haffner, S.M., Hamm, C.W., Hankey, G.J., Johnston, S.C., Mak, K.H., Mas, J.L., Montalescot, G., Pearson, T.A., Steg, P.G., Steinhubl, S.R., Weber, M.A., Brennan, D.M., Fabry-Ribaudo, L., Booth, J., Topol, E.J.; CHARISMA Investigators., 2006. Clopidogrel and Aspirin versus Aspirin Alone for the Prevention of Atherothrombotic Events. N. Engl. J. Med. 354, 1706-1717.

Bozina, N., Granic, P., Lalic, Z., Tramisak, I., Lovric, M., Rukavina, A., 2003. Genetic polymorphisms of Cytochrom P450: CYP2C9, CYP2C19 and CYP2D6 in Croatian population. Croatian Medical Journal 44(4), 425-428.

Collet, J.P., Hulot, J.S., Pena, A., Villard, E., Esteve, J.B., Silvain, J., Payot, L., Brugier, D., Cayla, G., Beygui, F., Bensimon, G., Funck-Brentano, C., Montalescot, G., 2009. Cytochrome P450 2C19 polymorphism in young patients treated with clopidogrel after myocardial infarction: A cohort study. Lancet. 373, 309-317.

Dahl, M.L. and Gunes, A., 2010. Implications of Inter-Individual Differences in Clopidogrel Metabolism, with Focus on Pharmacogenetics. Pharmaceuticals 3, 782-794.

Fontana, P., Hulot, J.S., De Moerloose, P., Gaussem, P., 2007. Influence of CYP2C19 and CYP3A4 gene polymorphisms on clopidogrel responsiveness in healthy subjects. J. Thromb. Haemost. 5, 2153-2155.

Gladding, P., Webster, M., Zeng, I., Farrell, H., Stewart, J., Ruygrok, P., Ormiston, J., El-Jack, S., Armstrong, G., Kay, P., Scott, D., Gunes, A., Dahl ML., 2008. The pharmacogenetics and pharmacodynamics of clopidogrel response: an analysis from the PRINC (Plavix Response in Coronary Intervention) trial. JACC Cardiovasc Interv. 1(6), 620-627.

Geisler, T., Schaeffeler, E., Dippon, J., Winter, E., Buse, V., Bischofs, C., Zuern, C., Moerike, K., Gawaz, M., Schwab, M., 2008. CYP2C19 and nongenetic factors predict poor responsiveness to clopidogrel loading dose after coronary stent implantation. Pharmacogenomics 9, 1251- 1259.

Goldstein, J.A., Ishizaki, T., Chiba, K., De Morais, S.M., Bell, D., Krahn, P.M., Evans, Da., 1997. Frequencies of the defective CYP2C19 alleles responsible for the mephenytoin poor metabolizer phenotype in various Oriental, Caucasian, Saudi Arabian and American black populations. Pharmacogenetics 7, 59-64.

Goldstein J.A., 2001. Clinical relevance of genetic polymorphisms in the human CYP2C subfamily. Br J Clin Pharmacol. 52, 349-355.

Gurbel, P.A., Bliden, K.P., Hiatt, B.L., O’Connor, C.M., 2003. Clopidogrel for Coronary Stenting Response Variability, Drug Resistance, and the Effect of Pretreatment Platelet Reactivity. Circulation. 107, 2908-2913.

Gurbel, P.A., Tantry, U.S., 2007. Clopidogrel resistance? Thromb Res. 120(3), 311-321.

Harmsze, A.M., van Werkum, J.W., Ten Berg, J.M., Zwart, B., Bouman, H.J., Breet, N.J., van 't Hof, A.W., Ruven, H.J., Hackeng, C.M., Klungel, O.H., de Boer, A., Deneer, V.H., 2010. CYP2C19*2 and CYP2C9*3 alleles are associated with stent thrombosis: a case-control study. Eur Heart J. 31(24), 3046-3053.

Hulot, J.S., Bura, A., Villard, E., Azizi, M., Remones, V., Goyenvalle, C., Aiach, M., Lechat, P., Gaussem, P., 2006. Cytochrome P450 2C19 loss-of-function polymorphism is a major determinant of clopidogrel responsiveness in healthy subjects. Blood. 108, 2244-2247.

Ingelman-Sundberg, M., Sim, S.C., Gomez,A., Rodriguez-Antona, C., 2007. Influence of cytochrome $\mathrm{P} 450$ polymorphisms on drug therapies: pharmacogenetic, pharmacoepigenetic and clinical aspects. Pharmacol Ther. 116(3), 496-526.

Marín, F., González-Conejero, R., Capranzano, P., Bass, T.A., Roldán, V., Angiolillo, D.J., 2009. Pharmacogenetics in cardiovascular antithrombotic therapy. J. Am. Coll. Cardiol. 54(12), 1041-1057.

Mega, J.L., Close, S.L., Wiviott, S.D., Shen, L., Hockett, R.D., Brandt, J.T., Walker, J.R., Antman, E.M., Macias, W., Braunwald, E., Sabatine, M.S., 2009. Cytochrome p-450 polymorphisms and response to clopidogrel. N. Engl. J. Med. 360(4), 354-362.

Paré, G., Mehta, S.R., Yusuf, S., Anand, S.S., Connolly, S.J., Hirsh, J., Simonsen, K., Bhatt, D.L., Fox, K.A., Eikelboom, J.W., 2010. Effects of CYP2C19 genotype on outcomes of clopidogrel treatment. N. Engl. J. Med. 363(18), 17041714.

Sabatine, M.S., Cannon, C.P., Gibson, C.M., López-Sendón, J.L., Montalescot, G., Theroux, P., Claeys, M.J., Cools, F., Hill, K.A., Skene, A.M., McCabe, C.H., Braunwald, E.; CLARITY-TIMI 28 Investigators., 2005. Addition of clopidogrel to aspirin and fibrinolytic therapy for myocardial 
infarction with ST-segment elevation. N. Engl. J. Med. 352, 1179-1189.

Shuldiner, A.R., O’Connell, J.R., Bliden, K.P., Gandhi, A., Ryan, K., Horenstein, R.B., Damcott, C.M., Pakyz, R., Tantry, U.S., Gibson, Q., Pollin, T.I., Post, W., Parsa, A., Mitchell, B.D., Faraday, N., Herzog, W., Gurbel, P.A., 2009. Association of cytochrome P450 2C19 genotype with the antiplatelet effect and clinical efficacy of clopidogrel therapy. JAMA. 302(8), 849-857.

Simon, T., Verstuyft, C., Mary-Krause, M., Quteineh, L., Drouet, E., Méneveau, N., Steg, P.G., Ferrières, J., Danchin, N., Becquemont, L.; French Registry of Acute ST-Elevation and Non-ST-Elevation Myocardial Infarction (FAST-MI) Investigators., 2009. Genetic determinants of response to clopidogrel and cardiovascular events. N. Engl. J. Med. 360, $363-375$.

Steinhubl, S.R., Talley, J.D., Braden, G.A., Tcheng, J.E., Casterella, P.J., Moliterno, D.J., Navetta, F.I., Berger, P.B.,
Popma, J.J., Dangas, G., Gallo, R., Sane, D.C., Saucedo, J.F., Jia, G., Lincoff, A.M., Theroux, P., Holmes, D.R., Teirstein, P.S., Kereiakes, D.J., 2001. Point-of-care measured platelet inhibition correlates with a reduced risk of an adverse cardiac event after percutaneous coronary intervention: results of the GOLD (AU-Assessing Ultegra) multicenter study. Circulation. 29; 103(21), 2572-2578.

Yamada, H., Dahl, M., Lannfelt, L., Viitanen, M., Winblad, B., Sjoqvist, F., 1998. CYP2D6 and CYP2C19 genotypes in an elderly Swedish population. Eur. J. Clin. Pharmacol. 54, 479-481.

Yusuf, S., Zhao, F., Mehta, S.R., Chrolavicius, S., Tognoni, G., Fox, K.K., 2001. Clopidogrel in Unstable angina to prevent Recurrent Events trial (CURE) Investigators. Effects of clopidogrel in addition to aspirin in patients with acute coronary syndromes without ST-segment elevation. N. Engl. J. Med. 345, $494-502$.

\title{
Резиме
}

\section{Асоцијација помеѓу СУР2С19*2 полиморфизам и клиничкиот исход од терапија со клопидогрел во Република Македонија}

\author{
Александра Капедановска Несторовска, ${ }^{1}$ Александра Димитровска Цветковска, ${ }^{2}$ \\ Љубица Шутуркова ${ }^{1}$
}

\author{
'Фармацевтски факултет, Универзитет „Св. Кирил и Методиј“- Скопје, Р. Македонија \\ ${ }^{2}$ Специјализирана болница за хирурики болести ,, Филип II“ - Скопје, Р. Македонија.
}

Клучни зборови: клопидогрел, Македонија, СҮР2С19*2, артеротромботски заболувања, несакани кардиоваскуларни настани

Клопидогрелот преставува терапија од избор за спречување на несакани кардиоваскуларни настани (исхемични напади и стент-тромбоза) кај пациетнти со атеротромботична болест и пациенти кои се подложени на перкутана коронарна интервенција, со или без стентирање. Се поголем е бројот на студии кои потврдуваат дека еднонуклеотидните полиморфизми (Single nucleotide polymorphisms-SNP) во гените кои ги кодираат ензимите од CYP 450 суперфамилијата, поточно оние од СҮР2С подфамилијата, се одговорни за клинички значајната интериндивидуална варијабилност во терапискиот исход на пациентите кои се на терапија со клопидогрел.

Целта на ова истражување беше да се одреди фрекфенцијата на застапеност на најчестата СҮР2С19 генетска варијацијаCYP2C19*2: 681G>A (rs4244285) во популација од Р. Македонија и да се утврди асоцијацијата со ризикот за појава на кардиоваскуларни несакани настани кај пациентите кои се на терапија со клопидогрел.

Фрекфенцијата на CYP2C19*2: 681G>A (rs4244285) полиморфизмот во популација од Р.Македонија, беше определена кај вкупно 198 испитаници, додека пак асоцијацијата со ризикот за појава несакани кардиоваскуларни настани и клиничкиот исход од терапијата со клопидогрел беа евалуирани кај вкупно 67 клопидогрел третирани пациенти, следени во период од најмалку 6 месеци (6-60 месеци) по иницијализација на терапијата со клопидогрел.

Фрекфенцијата на полиморфниот СҮР2С19*2 А алел, одговорен за намалениот метаболизам на клопидогрел во популација од Р.Македонија изнесува $18 \%$. Приближно 67\% од популацијата претставуваат “брзи метаболизатори”, $28 \%$ се “умерено брзи “ метаболизатори, додека пак 4.5 \% спаѓаат во групата на “спори” метаболизатори. Утврдена е статистички значајна асоцијација помеѓу CYP2C19*2 полиморфизмот и ризикот за појава на несакани кардиоваскуларни настани $(\mathrm{p}=0.0088)$. Имено, пациентите кои се "спори метаболизатори” имаат за приближно 6 пати поголем ризик за појава на несакани ефекти $(\mathrm{OR}=6.750,95 \% \mathrm{CI}$ : 1.186-38.410) во споредба со пациентите кои се класифицирани како “брзи” метаболизатори на клопидогрел. Генерално, ризикот за појава на несакан кардиоваскуларен настан при терапијата со клопидогрел е за 3 пати поголем кај носителите на само еден алел со редуцирана функција (A алел) споредба со пациентите кои не се носители на алелот со редуцирана функција (OR= 
3.188; 95\% CI= 1.437-7.058). Kaplan - Maier анализата за период на преживување без несакан настан покажа дека влијанието на CYP2C19*2 полиморфизмот е значајно корелирано со помал степен на преживување без несакан настан кај клопидогрел третирани пациентите кои се носители на AA генотипот ( $\log r a n k \mathrm{P}=0.0024)$ во споредба со оние кои се носители на GG или GA генотипот, односно кај пациентите - носители на само еден алел со редуцирана функција $(\log r a n k \mathrm{P}=0.0058)$. Фрекфенцијата на СYР2С19*2 полиморфизмот во популацијата од Р.Македонија е слична со фрекфенцијата на другите Европски популации. CYP2C19*2 полиморфизмот е асоциран со ризик за појава на несакани кардиоваскуларни настани при терапија со стандардни дози на клопидогрел како и со помал степен на преживување без појава на несакан настан кај пациенти со атеротромботични заболувања. 